\title{
Experimental Study on Floating LNG Bunkering Terminal for Assessment of Loading and Offloading Performance
}

\author{
Dong-Woo Jung@*, Yun-Ho Kim*, Seok-Kyu Cho,', Dong-Ho Jung ${ }^{*}$, Hong-Gun Sung ${ }^{*}$ and Sun-Hong Kwon ${ }^{* *}$ \\ *Offshore Plant Research Institute, KRISO, Daejon, Korea \\ * Department of Naval Architecture and Ocean Engineering, Pusan National University

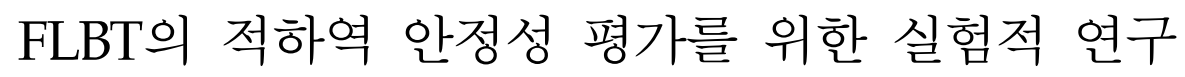
정동우(10* 김윤호
"한국해양과학기술원 부설 선박해양플랜트연구소 해양플랜트연구부 \\ *부산대학교 조선해양공학과
}

KEY WORDS: FLBT 부유식 LNG 벙커링 터미널, Loading arm and manifold 로딩암과 매니폴드, Loading and offloading operability 적하역 운용성, Relative motion 상대운동, Side by side moored vessel 병렬계류선박, Ocean engineering basin 해양공학수조

\begin{abstract}
In this study, the operability of an FLBT (floating LNG bunkering terminal) was evaluated experimentally. Model tests were conducted in the KRISO (Korea Research Institute of Ships and Ocean Engineering) ocean engineering basin. An FLBT, an LNG carrier, and two LNG bunkering shuttles were moored side by side with mooring ropes and fenders. Two white-noise wave cases, one irregular wave case, and various regular wave cases were generated. The relative local motions between each LNG loading arm and its corresponding manifold in the initial design configuration were calculated from measured 6-DOF motions at the center of gravity of each of the four vessels. Furthermore, the locations of the LNG loading arms and manifolds were varied to minimize the relative local motions.
\end{abstract}

\section{1. 서 론}

21세기 초부터 본격적으로 기후변화와 기상이변이 전 세계적으 로 나타남에 따라 국제해사기구(IMO, International Maritime Organization)에서 선박의 배출가스 규제에 나섰다. 이는 MARPOL (Marine polution) 73/78로 알려진 선박으로부터 오염 방지를 위한 국제협약(International convention for the prevention of marine pollution from ships)에서 지정된 것으로 2020년까지 선박의 배출가 스에 포함된 황산화물을 $0.5 \%$ 이하로, 특히 $\mathrm{ECA}($ Emission control areas)에서는 $0.1 \%$ 이하로 규제하고 있다. 이러한 환경 규제에 따라 청정연료인 LNG(Liquified natural gas)로 추진하는 선박에 대한 요 구가 높아지고 있으며, 이에 따라 2010년 이후부터 LNG 추진선박 뿐만 아니라 LNG 벙커링 셔틀(LNG-BS, LNG bunkering shuttle)의 요구 또한 늘어나고 있다. 여기서 $\mathrm{LNG}$ 벙커링이란 LNG 추진선박 에 $\mathrm{LNG}$ 를 주입하는 일련의 과정을 뜻한다.
벙커링 방법으로 크게 육상에서 수행되는 것과 해상에서 수 행되는 것으로 나눌 수 있다. 육상에서 벙커링을 수행할 경우 파랑에 대한 영향을 받지 않아 안정적인 작업이 가능하지만, 대 규모 인프라 구축이 필요하고 사고 시 인명피해가 크다는 특징 이 있는 반면 해상에서 수행할 경우 파랑에 의한 로딩암에서의 상대운동에 제약이 따르지만 육상대비 폭발에 대한 인명피해 우려가 적다는 특징이 있다. 본 연구에서는 해상 벙커링 방법에 대해 부유식 벙커링 터미널(FLBT, Floating LNG bunkering terminal)을 대상으로 하여 FLBT에 LNG 운반선(이하 LNGC)과 LNG-BS가 병렬계류시스템을 이용해 접안하여 LNGC로부터 공 급받은 $\mathrm{LNG}$ 를 $\mathrm{LNG-BS}$ 에 하역하는 절차로 운용된다.

병렬계류된 선박들의 운동 특성에 대해서는 많은 선행연구가 수행되었는데, LNG FPSO와 두 LNGC가 병렬 배치되었을 때 부유체 주위의 유동장 변화에 따른 운동응답 및 표류력 변화를 실험과 수치적으로 평가하였고(Hong et al., 2005), 고차 경계요

Received 27 January 2018, revised 19 February 2018, accepted 19 February 2018

Corresponding author Dong-Woo Jung: +82-42-866-3979, dwjung@kriso.re.kr ORCID: https://orcid.org/0000-0002-9154-8500

It is noted that this paper is revised edition based on proceedings of KAOST 2017 in 'Assessment of Operability with Respect to the Location of Loading Arm of Floating LNG Bunkering Terminal'

(c) 2018, The Korean Society of Ocean Engineers

This is an open access article distributed under the terms of the creative commons attribution non-commercial license (http://creativecommons.org/licenses/by-nc/3.0) which permits unrestricted non-commercial use, distribution, and reproduction in any medium, provided the original work is properly cited. 
소법을 적용하여 다물체 운동에 대해 수치적으로 접근하였다 (Choi and Hong, 2002). LNG-FPSO와 LNGC가 병렬계류되었을 때 파랑 중 운동 특성을 실험과 수치적인 방법으로 주로 차폐 효과에 대해 연구하였고(Kim et al., 2003), 서아프리카 투입을 위해 개발한 다소 작은 규모의 LNG-FPSO와 LNGC의 운동 응 답에 대한 연구를 수행하였다(Kim et al., 2017a). 두 부유체의 사파중 운동응답, 상대운동, 틈새유동 그리고 표류력 등 전반적 인 운동 응답에 대한 연구를 수행하였다(Fang and Kim, 1986; Fang and Chen, 2001; Fang and Chen, 2002). FLBT 관련된 선행 연구로는 FLBT의 3 \& 4-body 상태에서의 운동 특성에 대해 실 험 및 고차 경계요소법을 적용한 수치적 방법으로 연구하였고 (Kim et al., 2017b), FLBT의 로딩암 위치에 따른 운용성을 평가 하였다(Jung et al., 2017). 또한 은 본 연구와 유사한 개념으로 GIFT(Gas import floating terminal) 이라는 이름으로 부유식 LNG 터미널에 대해 GIFT 단독상태에서 계류계 성능과 슬로싱을 고 려한 운동특성을 검토하였고, $\mathrm{LNGC}$ 가 $\mathrm{GIFT}$ 에 접안할 때와 적 하역시 안전성을 평가하였다(Claes et al., 2007).

본 논문에서는 $\mathrm{FLBT}$ 와 작업 선박들의 운용 절차에 따라 FLBT에 1 척에서 3 척의 작업선이 병렬계류되어 있을 때 로딩암 과 매니폴드에서의 상대운동을 실험적으로 평가하였고, 더 나 아가 로딩암과 매니폴드의 위치를 다양하게 검토함으로써 상대 운동 특성을 분석하였다.

\section{2. 대상 모델}

$\mathrm{LNG}$ 의 적하역 공정에 있어 FLBT와 FLBT에 병렬계류된 작 업 선박들이 근접 배치됨에 따라 차폐효과, 상호 간섭효과에 따 른 운동 및 파랑 표류력 특성 변화를 실험적으로 평가하기 위 해 한국해양과학기술원 부설 선박해양플랜트 연구소의 해양공 학수조에서 FLBT, $170 \mathrm{~K}$ LNGC, $30 \mathrm{~K}$ LNG-BS 그리고 $5 \mathrm{~K}$ LNG-BS를 대상선으로 모형시험을 수행하였다. 각 부유체의 배 치는 Fig. 1에, 그리고 주요제원은 Table 1에 제시하였고 모형 축척비는 $1: 65$ 를 적용하였다.

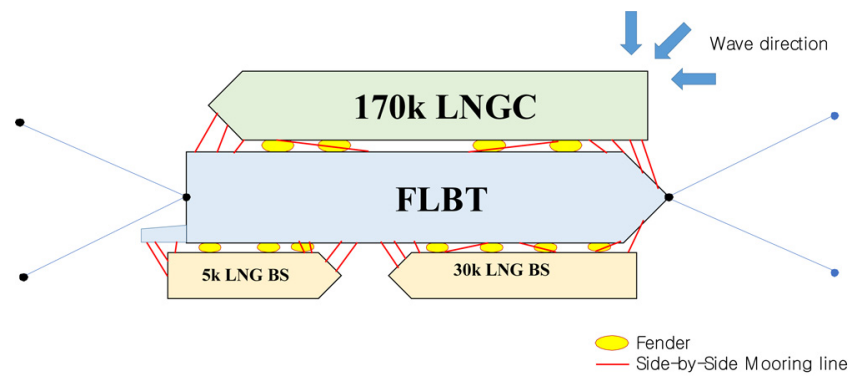

Fig. 1 Arrangement of FLBT, LNGC and two LNG BSs

Fig. 1에서 확인할 수 있는 바와 같이 $170 \mathrm{~K}$ LNGC와 $30 \mathrm{~K}$ LNG-BS의 선수 방향이 FLBT와 반대로 배치된다. FLBT의 위치 유지를 위해 파도의 1 차 주파수 성분의 영향을 받지 않도록 $20 \mathrm{kgf} / \mathrm{m}$ 의 강성을 가지는 스프링을 사용하여 네 지점에서 계류 하였다. 이 때 Surge, Sway 고유주기는 각각 실선 기준으로 110 초, 165 초로 확인되었다.

부유체간 충돌 방지를 위해 아래와 같이 두 종류의 공압 펜더 가 고려되었으며, 배수량이 큰 $170 \mathrm{~K} \mathrm{LNGC}$ 에는 지름 $4.5 \mathrm{~m}$ 급의 펜더가, 배수량이 상대적으로 적은 $30 \mathrm{~K} \mathrm{LNG-BS와} 5 \mathrm{~K}$ LNG-BS 의 경우 $3.0 \mathrm{~m}$ 급 펜더가 사용되었다.

- $\Phi 4.5 \mathrm{~m} \times 7.0 \mathrm{~m}$ (Initial inner pressure of $80 \mathrm{kPa}$ ): for $170 \mathrm{~K}$ LNGC

- $\Phi 3.0 \mathrm{~m} \times 5.0 \mathrm{~m}$ (Initial inner pressure of $80 \mathrm{kPa}$ ): for $30 \mathrm{~K} \&$ $5 \mathrm{~K}$ LNG BS

각 펜더의 변위와 힘에 대한 관계는 Fig. 2에 제시하였다. 그 래프에서 비선형 특성 값들과 이를 $35 \%, 60 \%$ 까지 선형으로 근 사 했을 때에 대해 제시하였고, 실제 펜더는 $60 \%$ 의 압축 까지 가능하지만 본 실험에서는 실제 제원과 스프링이 근접하게 모 사 가능한 $35 \%$ 압축 까지만 선형 근사 하였다.

병렬계류삭의 경우 모형선의 설치를 고려하여 실선의 두 가 닥을 하나로 모델링하였고, 각 계류삭의 강성은 병렬계류이므 로 식 (1)로 계산하였다.

Table 1 Main characteristics of operating vessels

\begin{tabular}{cccccc}
\hline \hline Item & Unit & FLBT & 170K LNGC & 30K LNG-BS & 5K LNG-BS \\
\hline Loading condition & - & Design condition & Design condition & Ballast condition & Ballast condition \\
Length between perpendicular & {$[\mathrm{m}]$} & 326.0 & 282.2 & 162.0 & 91.2 \\
Breadth & {$[\mathrm{m}]$} & 60.0 & 45.5 & 26.5 & 17.0 \\
Depth & {$[\mathrm{m}]$} & 32.7 & 26.0 & 15.0 & 10.0 \\
Draft & {$[\mathrm{m}]$} & 13.5 & 12.0 & 5.08 & 4.3 \\
Displacement & {$\left[\mathrm{m}^{3}\right]$} & $2.39 \mathrm{e} 05$ & $1.11 \mathrm{e} 05$ & $1.69 \mathrm{e} 04$ & $4.75 \mathrm{e} 03$ \\
Water plane Area & {$\left[\mathrm{m}^{2}\right]$} & $1.88 \mathrm{e} 04$ & $1.11 \mathrm{e} 04$ & $3.59 \mathrm{e} 03$ & $1.38 \mathrm{e} 03$ \\
Center of gravity $(x, y, z)$ & {$[\mathrm{m}]$} & $-0.695,0.0,3.295$ & $1.27,0.0,4.75$ & $5.21,0.0,2.74$ & $3.12,0.0,0.25$ \\
Center of buoyancy $(x, y, z)$ & {$[\mathrm{m}]$} & $0.8,0.0,-6.6$ & $-2.5,0.0,-5.7$ & $4.5,0.0,-2.4$ & $6.5,0.0,-2.0$ \\
Radius of gyration in poll & {$[\mathrm{m}]$} & 16.255 & 18.78 & 9.81 & 6.51 \\
Radius of gyration in pitch & {$[\mathrm{m}]$} & 87.082 & 65.29 & 43.25 & 24.95 \\
Radius of gyration in yaw & {$[\mathrm{m}]$} & 87.867 & 65.29 & 43.25 & 24.95 \\
Transverse metacenter height & {$[\mathrm{m}]$} & 13.51 & 4.257 & 18.616 & 3.20 \\
Roll natural period & {$[\mathrm{sec}]$} & 12.255 & & 9.52 & 7.577 \\
\hline
\end{tabular}




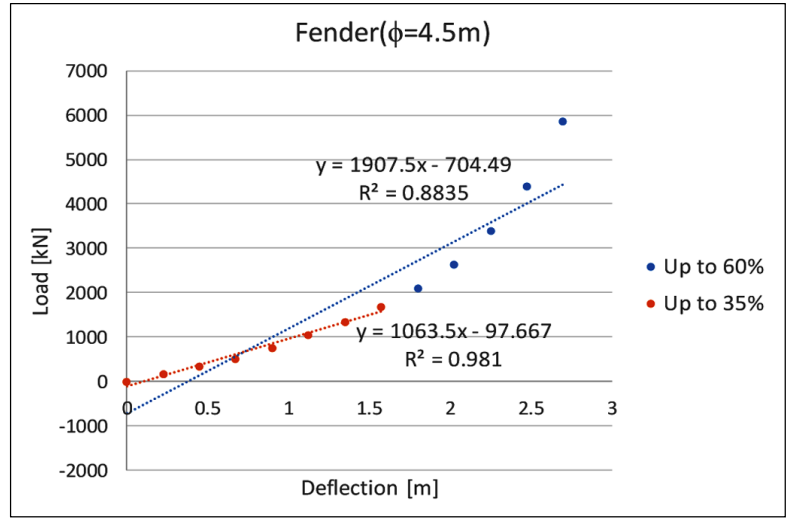

Fig. 2 Relation between deflection and load of fender

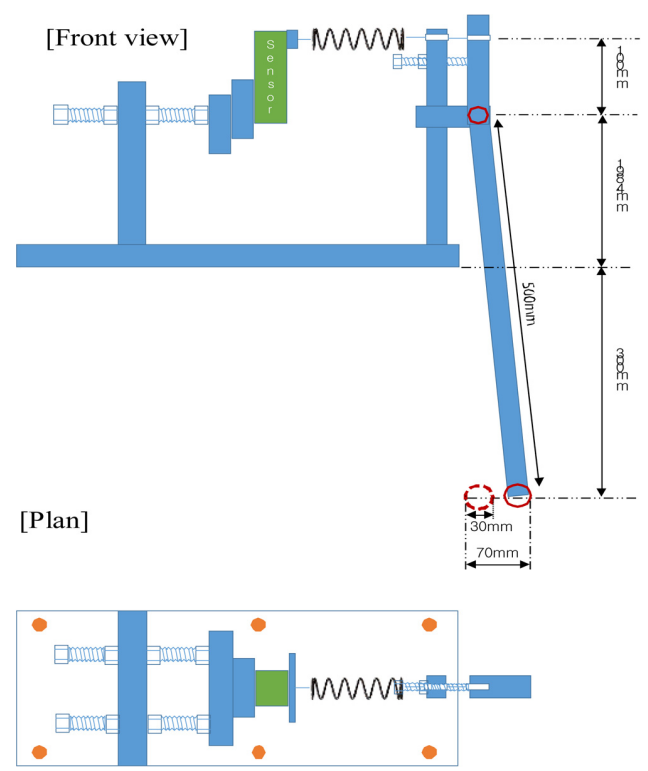

Fig. 3 Test equipment of side by side mooring system
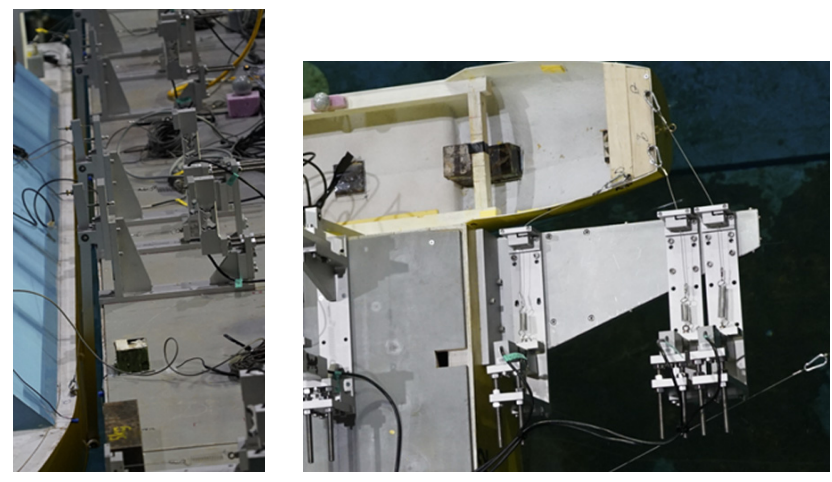

Fig. 4 Test setup of FLBT, LNGC and two LNG-BS

$$
k_{e q}=k_{1}+k_{2}
$$

계류삭과 펜더를 모사하기 위해 Fig. 3에서 제시한 치구를 모 델링하여 사용하였다. 모두 굽힘(Bending) 형식의 로드셀을 사 용하여 힘을 계측하였다. 계류삭의 경우 마찰력을 최소화하기 위한 도르레를 적용하였고, 펜더는 지렛대 원리를 이용하여 힘 을 계측하였다. 특히 펜더 모델의 경우 힌지에서 센서 연결부와
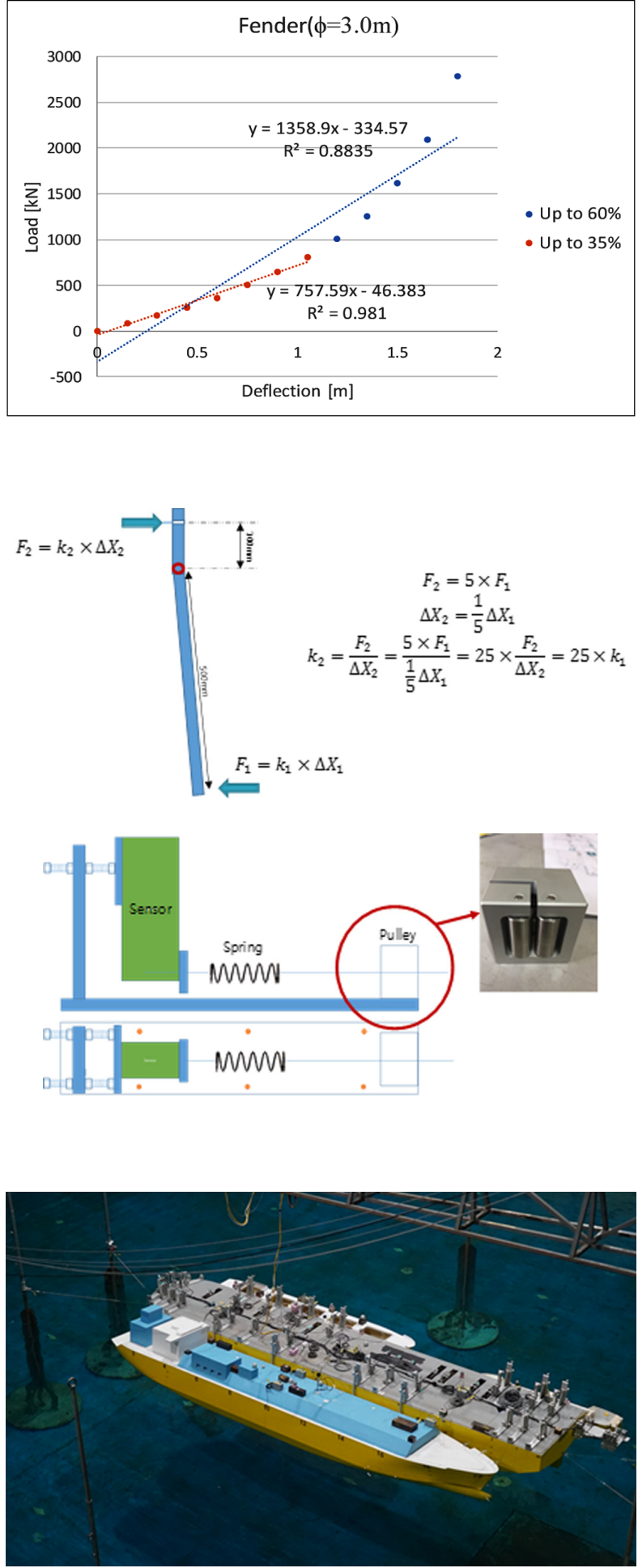

바의 끝단까지의 거리 비가 1:5이므로 여기에 적용한 스프링은 25 배 큰 강성을 적용하였다.

Fig. 4에는 모형시험에서 펜더와 계류삭이 설치된 모습과, FLBT, LNGC 그리고 두 LNG-BS가 수조에 설치된 모습을 제시 하였다. 모형선을 설치한 후 FLBT와 LNGC 사이 간격은 실선 기 준 $4.0 \mathrm{~m}, \mathrm{FLBT}$ 와 두 $\mathrm{LNG}-\mathrm{BS}$ 사이 간격은 실선기준 $2.7 \mathrm{~m}$ 가 되도 록 계류삭의 초기 장력과 펜더의 초기 압축력을 조절하였다. 


\section{3. 실험 조건}

실험에서 고려한 파도 조건은 규칙파, 불규칙파 그리고 백색 잡음파 조건이다. 규칙파의 경우 파고를 $2.0 \mathrm{~m}$ 로 고정하고 주기 를 틈새유동, 각 부유체의 고유주기를 포함하여 Table 2과 같이 모두 15 개의 조건을 선정하였다. 불규칙파의 경우 본 FLBT의 투입 후보지의 1 년 주기 조건으로 실선 3 시간에 대응되는 시간 으로 생성하였고 투입 후보지가 연안임을 감안하여 JONSWAP (JOint North Sea WAve Project) 스펙트럼을 적용하였다. 백색잡 음파는 응답의 비선형성 여부를 확인하기 위해 유의파고 $2.0 \mathrm{~m}$,

Table 2 Condition of regular waves in real scale

\begin{tabular}{ccccc}
\hline \hline ID & $\omega[\mathrm{rad} / \mathrm{s}]$ & Period [sec] & Height $[\mathrm{m}]$ & Remark \\
\hline REG01 & 0.300 & 20.944 & 2.0 & \\
REG02 & 0.338 & 18.617 & 2.0 & Troll (170 K) \\
REG03 & 0.400 & 15.708 & 2.0 & \\
REG04 & 0.512 & 12.255 & 2.0 & \\
REG05 & 0.571 & 11.004 & 2.0 & Troll (FLBT) \\
REG06 & 0.616 & 10.208 & 2.0 & \\
REG07 & 0.660 & 9.520 & 2.0 & Troll (30 K) \\
REG08 & 0.700 & 8.976 & 2.0 & Gap resonance \\
REG09 & 0.720 & 8.727 & 2.0 & Gap resonance \\
REG10 & 0.770 & 8.160 & 2.0 & Gap resonance \\
REG11 & 0.829 & 7.579 & 2.0 & Troll (5 K) \\
REG12 & 0.900 & 6.981 & 2.0 & \\
REG13 & 0.970 & 6.478 & 2.0 & Gap resonance \\
REG14 & 1.000 & 6.283 & 2.0 & Gap resonance \\
REG15 & 1.100 & 5.712 & 2.0 & Gap resonance \\
\hline
\end{tabular}

Table 3 Condition of irregular waves in real scale

\begin{tabular}{cccccc}
\hline \hline ID & $\begin{array}{c}\mathrm{Hs} \\
{[\mathrm{m}]}\end{array}$ & $\begin{array}{c}\mathrm{Tp} \\
{[\mathrm{sec}]}\end{array}$ & $\gamma$ & $\begin{array}{c}\text { Current Vel. } \\
{[\mathrm{m} / \mathrm{s}]}\end{array}$ & Remark \\
\hline WNT 2 m & 2.0 & $5 \sim 25$ & - & - & White noise \\
WNT 4 m & 4.0 & $5 \sim 25$ & - & - & White noise \\
IRW01 & 2.1 & 6.02 & 3.3 & - & JONSWAP \\
IRW01-Vc & 2.1 & 6.02 & 3.3 & 1.0 & Irr. w/ current \\
\hline
\end{tabular}

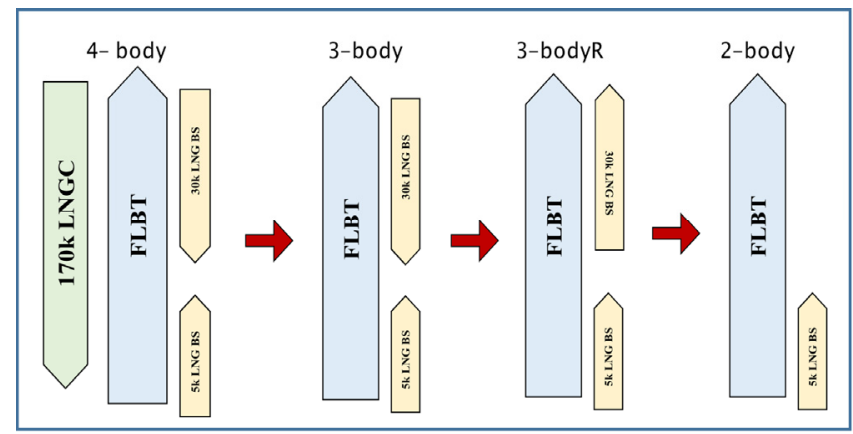

Fig. 5 Vessel arrangements for the side by side moored tests

$4.0 \mathrm{~m}$ 에 대해 주기 5 25초까지 생성하였고, Table 3에 백색잡음 파 및 불규칙파 조건에 대해 제시하였다.

파향은 FLBT 기준으로 선수파, 선수사파, 횡파 조건을 고려 하였는데, 선수사파와 횡파의 경우 배수량이 상대적으로 적은 LNG-BS로 파가 입사할 경우 운용성 확보가 힘들기 때문에 $\mathrm{LNGC}$ 방향으로 입사되는 조건만 고려하였다. 횡파의 경우 실 험 도중 운동 응답이 상당히 커 운용이 불가하다는 판단아래 본 논문에서는 결과를 제외하였다.

FLBT와 각 작업선들의 배치 조건은 Fig. 5 와 같이 모두 네 가지

Table 4 Test matrix of side by side moored condition

\begin{tabular}{|c|c|c|c|c|c|c|c|c|}
\hline \multirow[b]{2}{*}{ Wave ID } & \multicolumn{2}{|c|}{ 4-body } & \multicolumn{2}{|c|}{ 3-body } & \multicolumn{2}{|c|}{ 3-bodyR } & \multicolumn{2}{|c|}{ 2-body } \\
\hline & $\begin{array}{c}\text { Test ID } \\
{\left[\theta=180^{\circ}\right]}\end{array}$ & $\begin{array}{c}\text { Test ID } \\
{\left[\theta=225^{\circ}\right]}\end{array}$ & $\begin{array}{c}\text { Test ID } \\
{\left[\theta=180^{\circ}\right]}\end{array}$ & $\begin{array}{c}\text { Test ID } \\
{\left[\theta=225^{\circ}\right]}\end{array}$ & $\begin{array}{c}\text { Test ID } \\
{\left[\theta=180^{\circ}\right]}\end{array}$ & $\begin{array}{c}\text { Test ID } \\
{\left[\theta=225^{\circ}\right]}\end{array}$ & $\begin{array}{c}\text { Test ID } \\
{\left[\theta=180^{\circ}\right]}\end{array}$ & $\begin{array}{c}\text { Test ID } \\
{\left[\theta=225^{\circ}\right]}\end{array}$ \\
\hline WNT $2 \mathrm{~m}$ & 501 & 601 & 531 & 631 & $531-1$ & $631-1$ & 561 & 661 \\
\hline WNT $4 \mathrm{~m}$ & 503 & 603 & 533 & 633 & $533-1$ & & 563 & 663 \\
\hline IRW01 & 505 & 605 & 535 & 635 & $535-1$ & $635-1$ & 565 & 665 \\
\hline IRW01-Vc & 508 & 608 & 538 & 638 & & & 568 & 668 \\
\hline REG01 & 510 & 611 & 540 & 640 & $540-1$ & $640-1$ & 570 & 670 \\
\hline REG02 & 511 & 611 & 541 & 641 & $541-1$ & $641-1$ & 571 & 671 \\
\hline REG03 & 512 & 612 & 542 & 642 & $542-1$ & $642-1$ & 572 & 672 \\
\hline REG04 & 514 & 614 & 544 & 644 & $544-1$ & 644-1 & 574 & 674 \\
\hline REG05 & 515 & 615 & 545 & 645 & $545-1$ & $645-1$ & 575 & 675 \\
\hline REG06 & 516 & 616 & 546 & 646 & $546-1$ & $646-1$ & 576 & 676 \\
\hline REG07 & 518 & 618 & 548 & 648 & $548-1$ & $648-1$ & 578 & 678 \\
\hline REG08 & 519 & 619 & 549 & 649 & $549-1$ & $649-1$ & 579 & 679 \\
\hline REG09 & 520 & 620 & 550 & 650 & $550-1$ & $650-1$ & 580 & 680 \\
\hline REG10 & 522 & 622 & 552 & 652 & $552-1$ & $652-1$ & 582 & 682 \\
\hline REG11 & 523 & 623 & 553 & 653 & $553-1$ & $653-1$ & 583 & 683 \\
\hline REG12 & 524 & 624 & 554 & 654 & $554-1$ & $654-1$ & 584 & 684 \\
\hline REG13 & 526 & & 556 & & $556-1$ & & 586 & \\
\hline REG14 & 527 & & 557 & & $557-1$ & & 587 & \\
\hline REG15 & 528 & & 558 & & $558-1$ & & 588 & \\
\hline
\end{tabular}




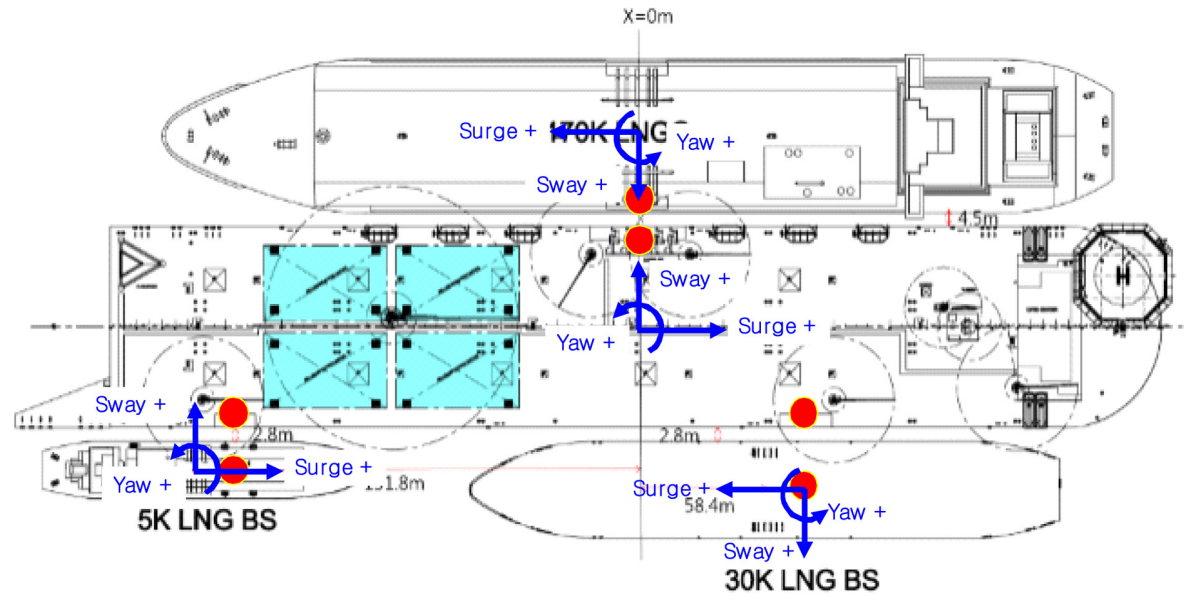

Fig. 6 Location of loading arm and manifold

조건을 고려하였으며, 특히 3-body 조건에 대해서는 30K LNG-BS 의 선수 방향에 따른 영향도 검토하였다. 제시한 환경 조건 및 작업 선의 배치에 따른 실험 조건을 Table 4에 정리하였다.

초기 설계 단계에서 결정된 로딩암과 매니폴드의 위치는 Fig. 6 과 Table 5 에 제시하였다. $\mathrm{LNGC}$ 의 경우 매니폴드는 좌현 끝단 에 위치하고 $\mathrm{LNG} \mathrm{BS}$ 의 경우 갑판중심선에 로딩암이 위치한다. 각각에 대응되는 $\mathrm{FLBT}$ 에서의 로딩암과 매니폴드는 절대좌표계 에서 $X$ 위치가 동일하다. Fig. 6에는 각 부유체의 물체고정좌표 계를 추가로 표기하였다. 6자유도 운동의 Surge는 선수방향,

Table 5 Location of loading arm and manifold

\begin{tabular}{ccccc}
\hline \hline Vessel & & FLBT & $\begin{array}{c}\text { Connected } \\
\text { vessel }\end{array}$ & $\begin{array}{c}\text { Relative } \\
\text { distance }\end{array}$ \\
\hline & $X[\mathrm{~m}]$ & 163.5 & 141.39 & 0.0 \\
FLBT - LNGC & $Y[\mathrm{~m}]$ & 30.0 & 22.75 & 4.0 \\
& $Z[\mathrm{~m}]$ & 32.7 & 28.0 & -3.15 \\
\hline \multirow{2}{*}{ FLBT - } & $X[\mathrm{~m}]$ & 215.58 & 79.871 & 0.0 \\
30K LNG-BS & $Y[\mathrm{~m}]$ & -30.0 & 0.0 & 15.95 \\
& $Z[\mathrm{~m}]$ & 32.7 & 21.0 & -3.28 \\
\hline & $X[\mathrm{~m}]$ & 38.7 & 50.88 & 0.0 \\
FLBT - & $Y[\mathrm{~m}]$ & -30.0 & 0.0 & 11.2 \\
5K LNG-BS & $Z[\mathrm{~m}]$ & 32.7 & 17.1 & -6.4 \\
\hline
\end{tabular}

Sway는 좌현방향, Heave는 수면 상부방향, Roll은 우현이 내려 갈 때, Pitch는 선수가 내려갈 때 그리고 Yaw는 선수가 좌현으 로 돌아갈 때 양의 값으로 정의된다.

Table 5의 좌표는 각 부유체의 선미수선(AP, After perpendicular), 갑판 중심선(CL, Center line), 기선(BL, Base line)을 기준으로 하고 상대 거리의 $Z$ 좌표는 흘수를 고려한 값이다. 이 때 $\mathrm{LNGC}$ 의 매니 폴드는 갑판 위 $2 \mathrm{~m}$ 에 위치하고 $30 \mathrm{~K} \mathrm{LNG-BS와} 5 \mathrm{~K} \mathrm{LNG-BS}$ 의 로 딩암은 갑판으로부터 각각 $6 \mathrm{~m}, 7.1 \mathrm{~m}$ 위에 위치한다고 가정하였다. 추가로 Table 5의 위치 포함하여 모두 15 위치에서의 상대운동을 평가하였고 Fig. 7에 위치를 제시하였다.

LNGC의 경우 Table 5의 좌료를 기준으로 $X$ 방향으로 $-30 \mathrm{~m}$ $+30 \mathrm{~m}$ 까지 $15 \mathrm{~m}$ 간격, $30 \mathrm{~K} \mathrm{LNG} \mathrm{BS}$ 는 $-24 \mathrm{~m} \sim+24 \mathrm{~m}$ 까지 $12 \mathrm{~m}$ 간 격 그리고 $5 \mathrm{~K} \mathrm{LNG} \mathrm{BS}$ 의 경우 $-20 \mathrm{~m} \sim+20 \mathrm{~m}$ 까지 $10 \mathrm{~m}$ 간격으로 모두 5개의 지점을 선정하였다. $Y$ 방향 좌표의 경우 선측, 갑판 중심선, 그리고 선측과 갑판중심선의 중간 위치로 3 위치를 고 려하여 평면상 각 부유체별 15 개의 위치에서 상대운동을 평가 하였다. 마찬가지로 로딩암과 대응되는 매니폴드의 $X$ 좌표는 절대좌표계에서 동일하다.

\section{4. 모형시험 결과}

4.1 데이터 후처리

실험에 있어 6자유도 운동은 비접촉식 광학카메라로 Fig. 6에

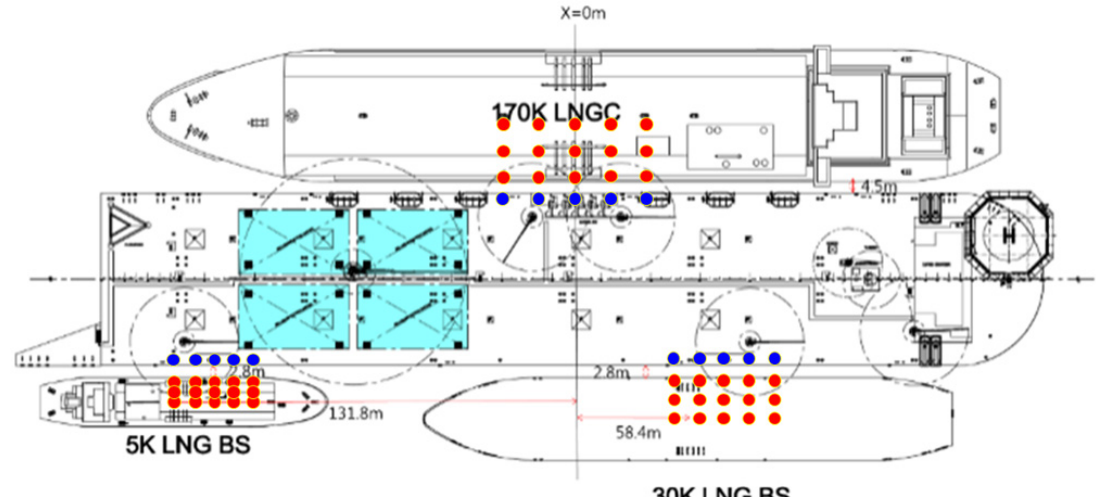

Fig. 7 Fifteen locations of loading arm and manifold for the relative motion contour 
서 제시한 좌표계와 같이 각 부유체의 물체고정좌표계를 기준으 로 계측하였다. 계측 값은 각 부유체의 무게 중심 $(\mathrm{COG}$, Center of gravity)을 기준으로 하고 있으며, $\mathrm{COG}$ 에서 $X, Y, Z$ 방향으로 떨어진 위치 $\left(x_{b,} y_{b}, z_{b}\right)$ 에서의 $X, Y, Z$ 방향 운동 $\left(x_{p}, y_{p}, z_{p}\right)$ 은 각각 아래 식 (2)에서 식 (4)로부터 계산할 수 있다.

$$
\begin{aligned}
& x_{p}=x-y_{b} \psi+z_{b} \theta \\
& y_{p}=y+x_{b} \psi-z_{b} \phi \\
& z_{p}=z-x_{b} \theta+y_{b} \phi
\end{aligned}
$$

식 (2)에서 식 (4)의 $x, y, z, \phi, \theta, \psi$ 는 각각 $\mathrm{COG}$ 에서의 Surge, Sway, Heave, Roll, Pitch, Yaw를 의미한다.

상대운동은 FLBT에서의 국부운동에서 계류된 부유체에서의 국부운동을 빼면 구할 수 있지만, 부유체의 선수 방향에 따라 물체고정좌표계가 달라지기 때문에 이를 고려하여 계산해야 한 다. 예를 들어 $\mathrm{FLBT}$ 와 $170 \mathrm{~K} \mathrm{LNGC}$ 의 선수방향이 다르므로 $X$, $Y$ 방향 운동의 부호가 반대이기 때문에 이 경우는 식 (5)에서 식 (7)과 같이 $X, Y, Z$ 방향 상대운동 $\left(R_{x}, R_{y}, R_{z}\right)$ 을 계산해야 한 다. 식 (5)에서 식 (7)의 아래첨자 $A$ 는 FLBT를, $B$ 는 $170 \mathrm{~K} \mathrm{LNGC}$ 를 의미한다.

$$
\begin{aligned}
& R_{x}=\left(x_{A}-y_{A} \psi_{A}+z_{Z} \theta_{A}\right)+\left(x_{B}-y_{B} \psi_{B}+z_{B} \theta_{B}\right) \\
& R_{y}=\left(y_{A}+x_{A} \psi_{A}-z_{A} \phi_{A}\right)+\left(y_{B}+x_{B} \psi_{B}-z_{B} \phi_{B}\right)
\end{aligned}
$$

$$
R_{z}=\left(z_{A}-x_{A} \theta_{A}+y_{Z} \phi_{A}\right)-\left(z_{B}-x_{B} \theta_{B}+y_{B} \phi_{B}\right)
$$

상대운동의 계산은 $R_{x}, R_{y}, R_{z}$ 의 시계열을 생성 후 규칙파와 백색잡음파에 대해서는 진폭응답함수(RAO, Response amplitude operator)로, 불규칙파에 대해서는 유의값(SDA, Significant double amplitude)로 평가하였다. RAO 도출을 위해 파 교정 시 FLBT의 중심 위치에서 계측한 신호로 실험 데이터를 동기화를 선행하 였고, 특히 규칙파의 경우 파가 완전히 발달한 후 반사파 영향 이 없는 구간을 선정하여 실효치(RMS, Root mean square) 기준 으로 계산하였다.

\section{2 상대운동 평가 결과}

Fig. 6의 설계된 로딩암 및 매니폴드 위치에서의 상대운동 특 성을 RAO 비교하여 Fig. 8에서 Fig. 12에 제시하였다. Fig. 8에서 는 4-body 조건에 대해 수직방향 상대운동 RAO를 제시하였는 데, heave 영향을 가장 크게 받으므로 파고에 따른 비선형성은 없는 것으로 확인되었다. 이 결과는 다른 배치 조건에서도 마찬 가지이다. 하지만 $X$ 방향 상대운동에는 배수량에 따른 비선형성 이 나타났는데, Fig. 9에서 보는바와 같이 $\mathrm{LNGC}$ 의 경우 비선형 성이 없으며, $30 \mathrm{~K} \mathrm{LNG-BS}$ 에는 주파수 $0.35 \mathrm{rad} / \mathrm{s}$ (18초) 부근에서 비선형성이 나타나고 $5 \mathrm{~K}$ LNG-BS의 경우 $0.43 \mathrm{rad} / \mathrm{s}$ (14.7초) 부근 에서 비선형성이 크게 나타났다. 이를 확인하기 위해 Fig. 10에 Surge RAO를 비교하였다.

Fig. 10 에서 파의 1 차 성분의 에너지가 존재하는 최대 주파수 인 $0.251 \mathrm{rad} / \mathrm{s}$ (25초)를 기준으로 저주파(LF, Low frequency), 고 주파(HF, High frequency) 영역으로 나누어 제시하였다. FLBT의

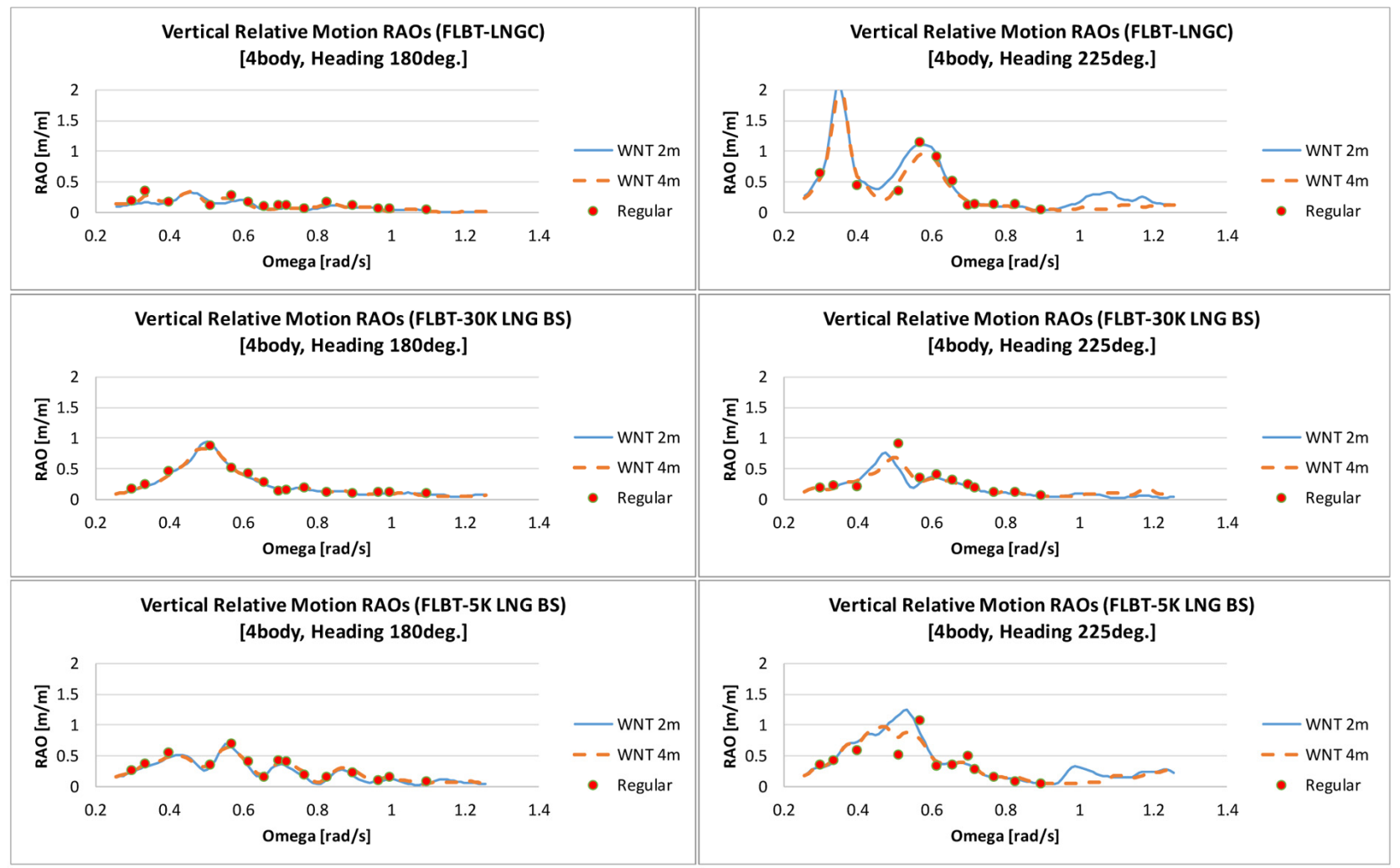

Fig. 8 Vertical relative motion RAOs in 4-body arrangement 


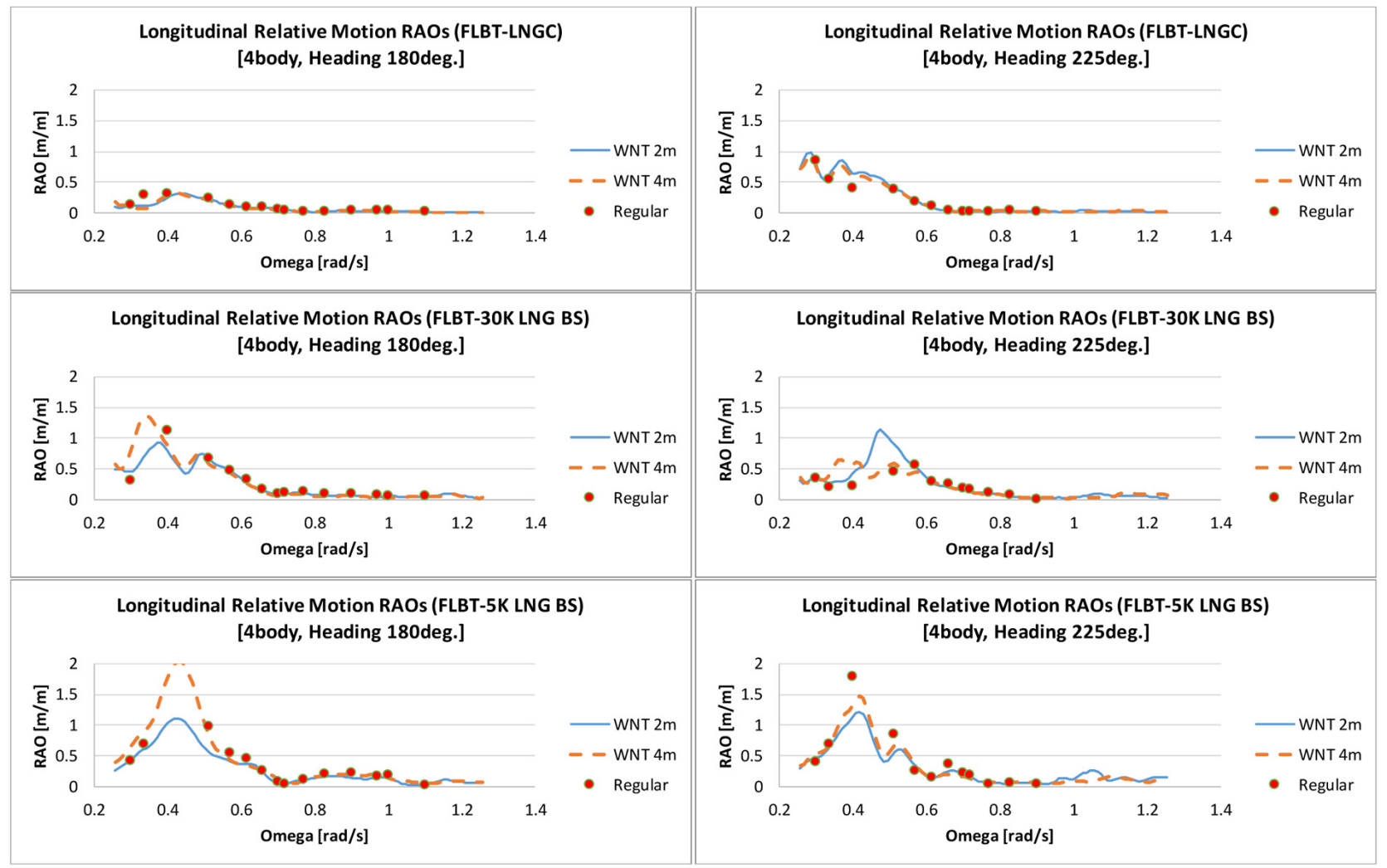

Fig. 9 Longitudinal relative motion RAOs in 4-body arrangement
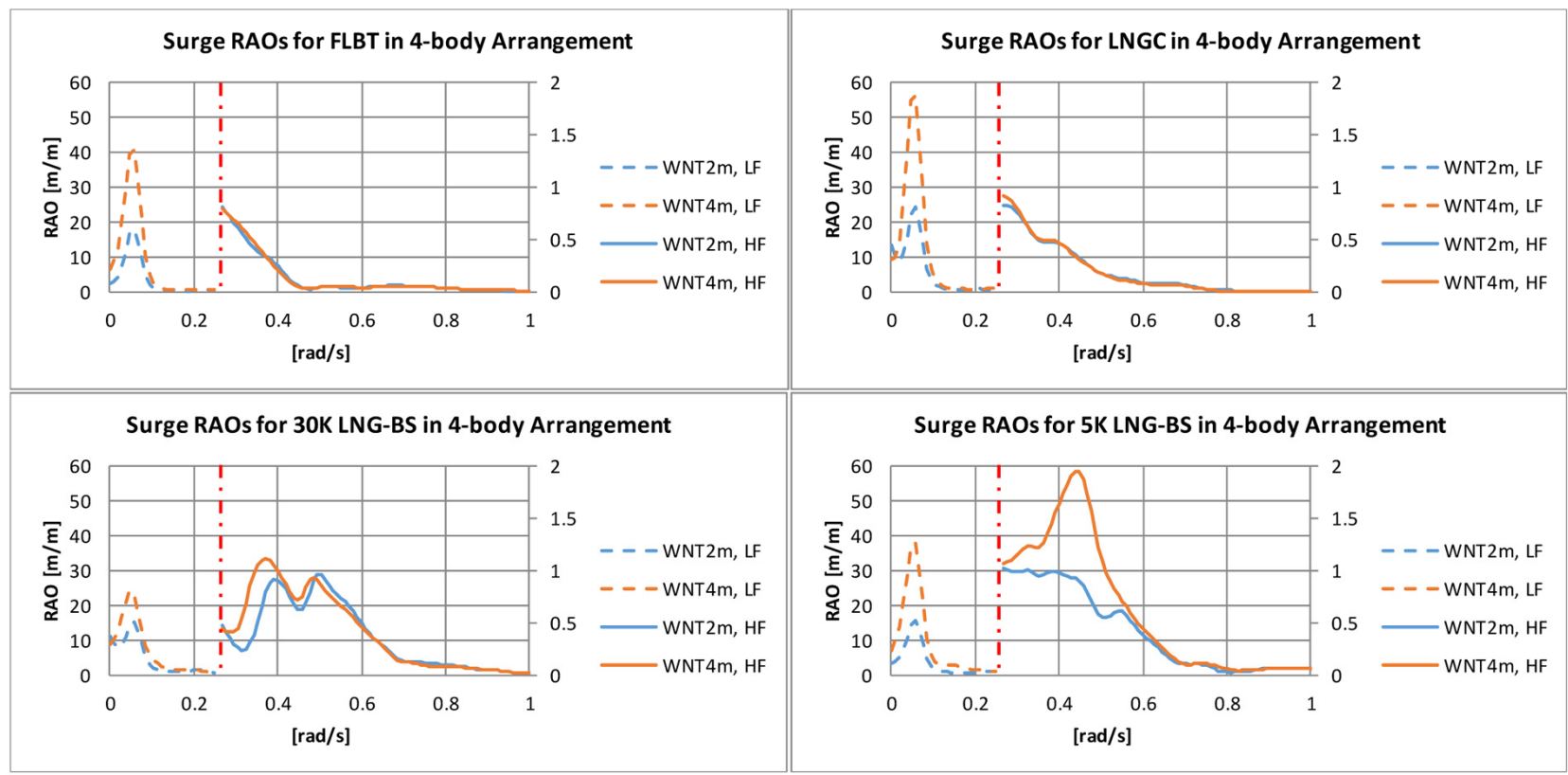

Fig. 10 Surge RAOs in 4-body arrangement

계류계에 의한 고유주파수 $0.057 \mathrm{rad} / \mathrm{s}$ (110초) 부근에서 동일한 응답특성을 보이고 있으며, 이는 작업선들이 FLBT에 병렬계류 됨에 따른 결과이다. 반면 $0.251 \mathrm{rad} / \mathrm{s}$ 이상의 파 1 차 성분에 대한 Surge 응답은 상이하다. 배수량이 큰 FLBT, $170 \mathrm{~K} \mathrm{LNGC}$ 의 경우 비선형성이 나타나지 않지만, $30 \mathrm{~K}$ LNG-BS에서는 $0.25 \sim 0.5 \mathrm{rad} / \mathrm{s}$ 영역에서 파고가 커짐에 따라 응답이 더욱 커지고, $5 \mathrm{~K}$ LNG-BS
에서는 비선형성이 확연하게 드러난다. 이는 FLBT 대비 $5 \mathrm{~K}$ LNG-BS의 배수량이 $1 / 50$ 수준이지만, 병렬계류계의 강성은 다 른 작업선과 비슷하기 때문에 고유주기가 짧아졌기 때문으로 사료된다.

3-Body, 3-BodyR 그리고 2-Body 조건에서의 FLBT와 $5 \mathrm{~K}$ LNG-BS의 상대운동 RAO를 Fig. 11 에 제시하였다. $30 \mathrm{~K}$ LNG-BS 


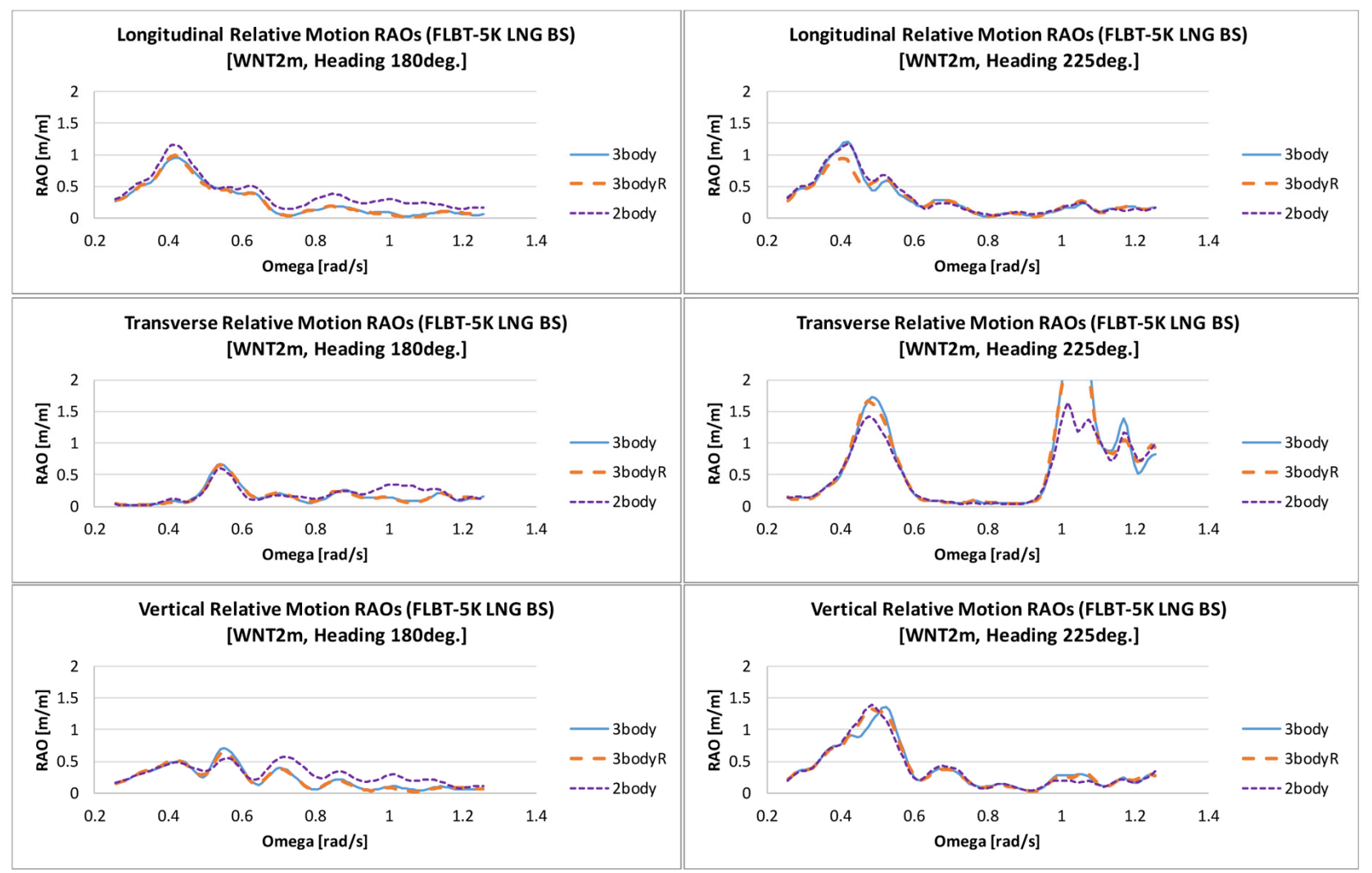

Fig. 11 Relative motion RAOs between FLBT and $5 \mathrm{~K}$ LNG-BS
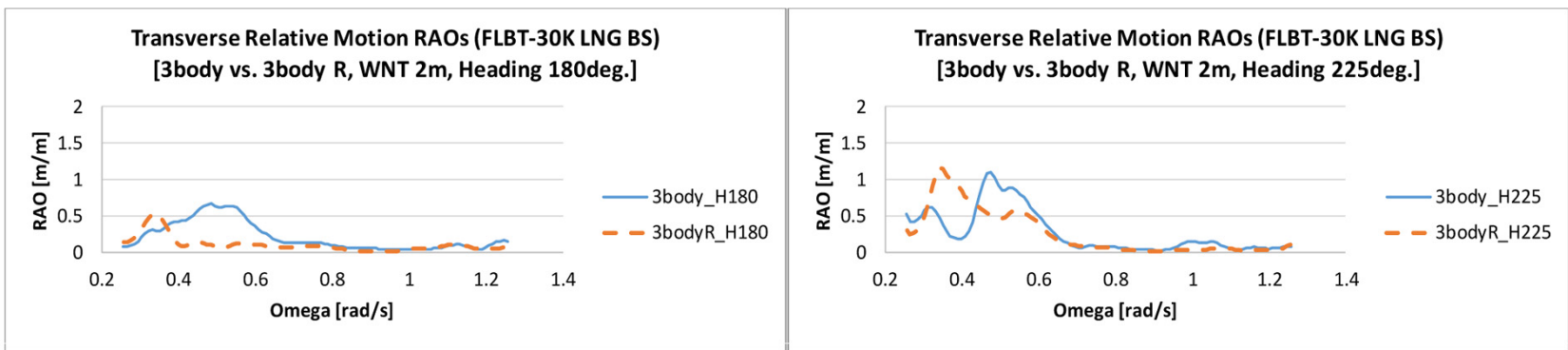

Fig. 12 Transverse relative motion RAOs between FLBT and $30 \mathrm{~K}$ LNG-BS

의 존재유무에 따라 차폐효과로 인한 $5 \mathrm{~K}$ LNG-BS의 상대운동 응 답이 작아짐을 확인할 수 있고, $30 \mathrm{~K}$ LNG-BS의 선수 방향에 따라 후류의 유동에는 큰 영향이 없으므로 $5 \mathrm{~K} \mathrm{LNG-BS}$ 의 상대운동 응 답이 대동소이함을 확인할 수 있다.

3-body 조건에 대해 $30 \mathrm{~K}$ LNG-BS의 선수방향에 따른 $30 \mathrm{~K}$ $\mathrm{LNG}-\mathrm{BS}$ 와 $5 \mathrm{~K}$ LNG-BS의 상대운동 RAO를 Fig. 12에 제시하였 다. 전체적으로 유사한 결과를 보이지만, $30 \mathrm{~K}$ LNG-BS의 선수 방향이 $\mathrm{FLBT}$ 와 동일할 경우 $X$ 방향 상대운동이 감소하였고, 전 체적인 운동 특성이 장주기 방향으로 이동하였다. 하지만 실해 역 파의 에너지가 $1 \mathrm{rad} / \mathrm{s}$ 전후에 존재함을 감안할 때 상대운동 응답 크기에는 별다른 영향이 없을 것으로 보인다.

4-body 조건에 대해 실해역 1년 주기파에서 조류의 존재 유무 에 따른 상대운동 응답을 $\mathrm{SDA}$ 기준으로 정리하여 Fig. 13 에 제 시하였다. Fig. 13에서 조류가 있을 경우 상대운동 응답이 소량 증가하는 것을 알 수 있으며, 보통 적하역 운용의 상대운동 한
계를 $1.5 \mathrm{~m}$ 이내라고 볼 때 선수파 조건에서는 안정적인 운용이 가능하고, 선수사파에서는 $30 \mathrm{~K} \mathrm{LNG-BS를} \mathrm{제외하고} \mathrm{운용이} \mathrm{불}$ 가하다는 결론을 얻을 수 있다. 운용한계는 $X, Y$ 방향 상대운동 에서 초과하는데 이러한 결과의 원인은 $X, Y$ 방향 상대운동의 핵심인자인 Surge, Sway의 시계열로부터 확인할 수 있다.

4-Body 조건에 대해 Surge, Sway 운동 시계열을 Fig. 14에 제 시하였다. Fig. 14의 시계열은 계측된 값으로 물체고정좌표계를 기준으로 하므로 선수파의 경우 FLBT의 Surge에 대한 작업선 들의 Surge의 위상차가 0 도이다. 즉, 모든 부유체들의 운동이 동일한 방향이므로 상대운동이 작게 평가되었다. 반면 선수사 파의 경우 FLBT의 Surge, Sway에 대해 $30 \mathrm{~K}$ 의 Surge, Sway 위 상차는 0 도에 가깝고, $\mathrm{LNGC}$ 와 $5 \mathrm{~K}$ LNG-BS의 위상차는 180 도 에 가깝다.

다음으로 설계된 로딩암과 매니폴드의 위치 주변 15 개 지점에 서 파 조건 IRW01에 대한 수직방향 상대운동을 평가하여 Fig. 


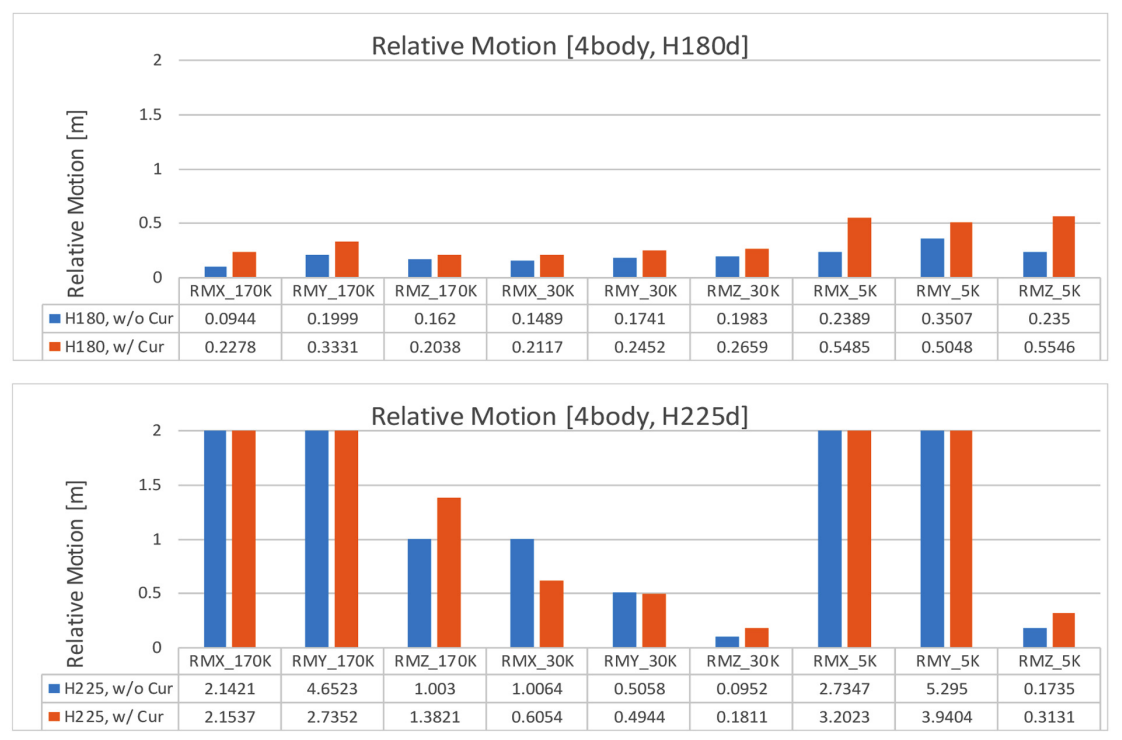

Fig. 13 Significant double amplitude of relative motion for 1-yr return period environmental condition

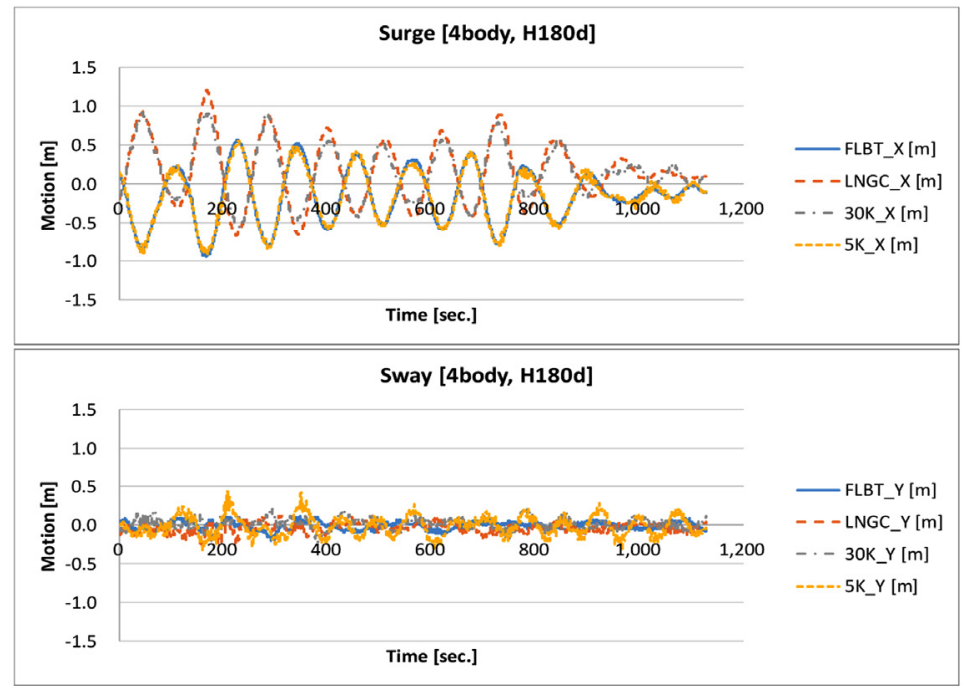

(a) Surge \& sway time series of heading 180 degrees in 4-body arrangement

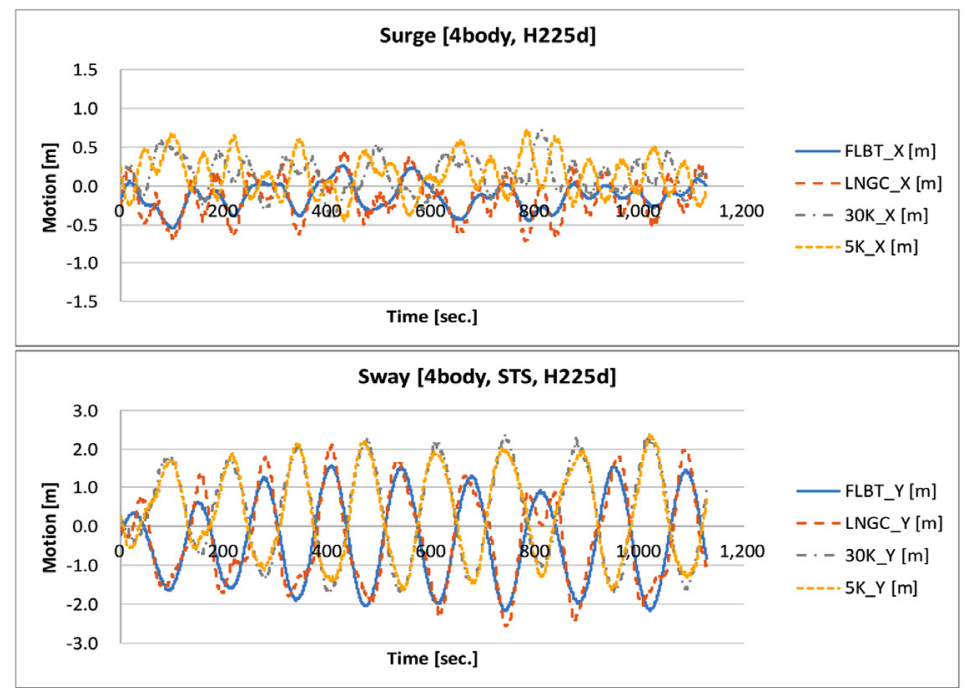

(b) Surge \& sway time series of heading 225 degrees in 4-body arrangement

Fig. 14 Time series of surge and sway for 1-yr return period environmental condition 

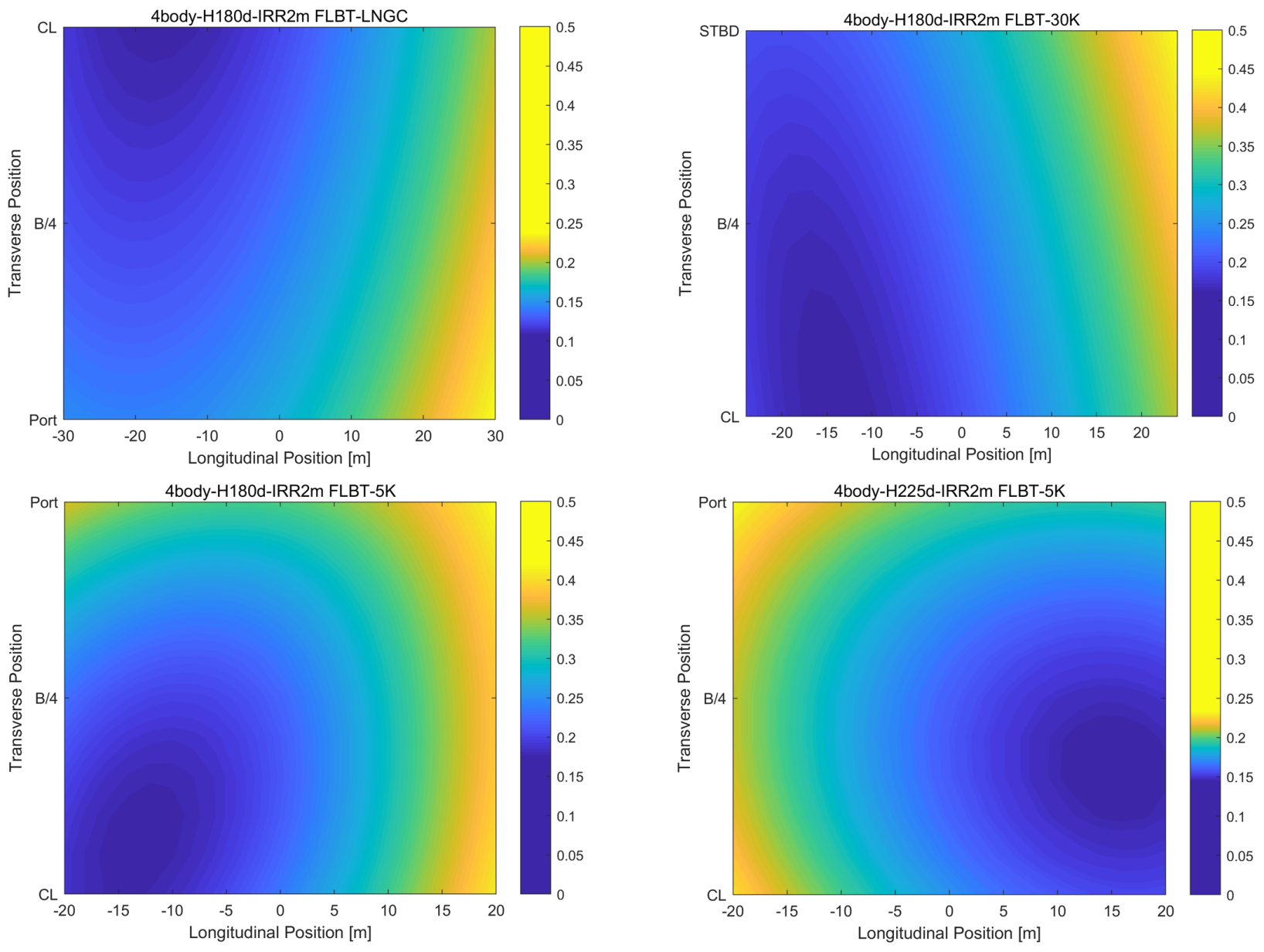

Fig. 15 Contour plot of vertical relative motion for 4-Body arrangement

15에 등고선 그래프로 제시하였다. 수직방향 상대운동은 roll에 영향을 받기 때문에 갑판중심선에 가까울수록 상대운동이 감소 됨을 확인할 수 있다. 또한 선수파 조건에서 FLBT와 선수방향 이 같을 경우는 선미 방향에서, FLBT와 선수방향이 다를 경우 선수 방향에서 수직방향 상대운동이 최소가 됨을 알 수 있다.

$5 \mathrm{~K} \mathrm{LNG-BS}$ 의 경우 선수파와 선수사파 조건에서 상대운동이 최소가 되는 위치가 달라졌다. 이는 Fig. 16의 4-Body 조건의 수 면 하부에서 본 배치와 같이 LNGC 방향으로 선수 사파에서 $5 \mathrm{~K}$ LNG-BS의 선수부는 FLBT에 의한 차폐효과가 적용되지만, 선

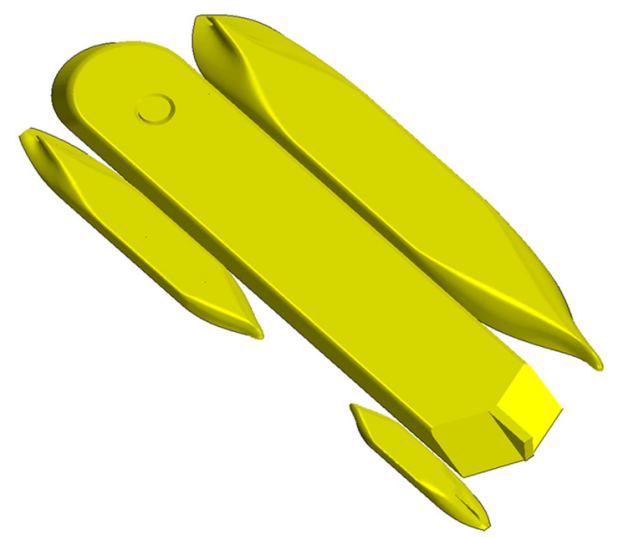

Fig. 16 4-body vessel arrangement
미부는 파랑기진력을 받기 때문에 운동의 중심이 선수방향으로 이동했기 때문으로 사료된다.

\section{5. 결 론}

본 논문에서는 $\mathrm{FLBT}$ 에 $170 \mathrm{~K} \mathrm{LNGC}, 30 \mathrm{~K} \mathrm{LNG}-\mathrm{BS}$ 그리고 $5 \mathrm{~K}$ LNG-BS가 병렬계류되어 있을 때 $\mathrm{LNG}$ 를 적하역함에 있어 운용 가능 여부 판단에 핵심이 되는 상대운동을 실험적으로 평가하 였다.

병렬계류선과 펜더의 강성을 실선과 유사하게 모사하여 4-body, 3-body, 3-bodyR 그리고 2-body 배치 조건에 대해 다양한 환경조 건을 검토하였다. 각 부유체에서 계측한 6 자유도 운동 신호를 바탕으로 로딩암과 매니폴드에서의 국부 운동을 계산하였고 부 유체의 선수 위치에 따른 좌표계를 고려하여 상대운동을 평가하 였고, 설계된 로딩암과 매니폴드 주위의 15 개 위치에서 상대운 동을 평가하여 아래와 같은 결론을 얻을 수 있었다.

(1) 높이방향 상대운동 RAO의 경우 파의 크기에 따른 비선형 특성이 없었지만, 길이 방향 상대운동에는 배수량에 따른 비선 형성이 나타났다. FLBT 배수량의 $1 / 50$ 수준인 $5 \mathrm{~K} \mathrm{LNG-BS}$ 의 경 우, 병렬계류계의 강성이 배수량에 비해 상당히 커 수평운동의 고유주기가 짧아졌기 때문으로 사료된다.

(2) 3-body 조건에 대해 $30 \mathrm{~K}$ LNG-BS의 선수방향이 FLBT와 
동일할 경우 길이방향 상대운동이 감소하였고, 전체적인 운동 특성이 장주기 방향으로 이동하였다. 하지만 실해역 파의 에너 지가 $1 \mathrm{rad} / \mathrm{s}$ 전후에 존재함을 감안할 때 상대운동 응답 크기에 는 별다른 영향이 없을 것으로 보인다. 또한 $30 \mathrm{~K} \mathrm{LNG-BS의} \mathrm{영}$ 향으로 $5 \mathrm{~K} \mathrm{LNG-BS}$ 에 차폐효과가 작용하여 운동 응답이 작아 짐을 확인할 수 있었다.

(3) 4-body 조건에 대해 실해역 1년 주기파에서 조류의 존재 유무에 따른 상대운동 응답에서 선수파의 경우는 상대운동이 작 아 안정적인 운용이 가능할 것으로 판단되지만, 선수 사파에서 는 FLBT와 작업선들의 Surge, Sway 위상이 180 도 차이남에 따라 길이, 폭방향 상대운동 응답이 상당히 커 운용이 불가할 것으로 보인다.

(4) 설계된 로딩암과 매니폴드 위치 주위로 15 개 지점에 대한 높이방향 상대운동을 평가하여 등고선 그래프로 경향을 파악하 였다. 높이방향 상대운동은 Roll 운동의 영향이 가장 적은 폭방 향 중심에서 가장 낮은 응답을 보였다. 또한 $5 \mathrm{~K} \mathrm{LNG-BS}$ 의 경 우 선수파와 선수사파 조건에서 상대운동이 최소가 되는 위치 가 달라졌는데, $5 \mathrm{~K} \mathrm{LNG-BS}$ 의 선수부는 FLBT에 의한 차폐효과 가 적용되지만, 선미부는 파랑기진력을 받기 때문에 운동의 중 심이 선수방향으로 이동했기 때문으로 사료된다.

본 연구를 바탕으로 향후에는 실험 결과로부터 해석 툴을 튜 닝한 후 다양한 환경조건에 대한 해석을 수행할 예정이다. 해석 결과를 바탕으로 해상에서 $\mathrm{LNG}$ 의 적하역 가능한 환경 조건을 제시하고 더 나아가 FLBT에 고려된 터널 추진기의 사용으로 파의 입사각을 제어할 경우 운용 범위가 어디까지 넓어지는지 에 대한 검토도 수행할 예정이다.

\section{후 기}

본 논문은 해양수산부의 국가R\&D사업인 '해상부유식 $\mathrm{LNG}$ 벙커링 시스템 기술개발 (PMS3731)' 및 선박해양플랜트연구소 의 주요사업인 '심해공학수조 기초 운용기술 개발 (PES9460)'에 서 수행되었습니다.

\section{References}

Hong, S.Y., Kim, J.H., Cho, S.K., Choi, Y.R., Kim, Y.S., 2005. Numerical and Experimental Study on Hydrodynamic Interaction of Side-by-side Moored Multiple Vessels. Ocean
Engineering, 32(7), 783-801.

Choi, Y.R., Hong, S.Y., 2002. An Analysis of Hydrodynamic Interaction of Floating Multi-body Using Higher-Order Boundary Element Method. Proceedings of the $12^{\text {th }}$ International Offshore and Polar Engineering Conference, 303-308.

Claes, L., Messager, J.C., Vaché, M., Lehalleur, J.P., 2007. GIFT (Gas Import Floating Terminal): A New Concept of Floating LNG Terminal. Offshore Technology Conference, OTC-19114MS.

Fang, M.C., Chen, G.R., 2001. The Relative Motion and Wave Elevation between Two Floating Structures in Waves. Proceedings of the 11th Intternational Offshore and Polar Engineering Conference, 361-368.

Fang, M.C., Chen, G.R., 2002. On Three-Dimensional Solutions of Drift Forces and Moments between Two Ships in Waves. Journal of Ship Research, 46(4), 280-288.

Fang, M.C., Kim, C.H., 1986. Hydrodynamically Coupled Motions of Two Ships Advancing in Oblique Waves. Journal of Ship Research, 30(3), 159-171.

Kim, M.S., Ha, M.K., Kim, B.W., 2003. Relative Motions between LNG-FPSO and Side-by-Side positioned LNG Carrier in Waves. Proceedings of the 13th International Offshore and Polar Engineering Conference, 210-217.

Kim, M.S., Morilhat, E., Nguyen, X.C., Kim, B.H., Jang, J.M., Jeong, H.S., 2017a. Offloading Operability of Small Scale AG FLNG With Side-by-Side Moored Small Scale LNG Carrier in Offshore West Africa. ASME 2017 36th International Conference on Ocean, Offshore and Arctic Engineerin, OMAE2017-62608, V001T01A034.

Kim, Y.H., Cho, S.K., Jung, D.W., Jung, H.W., Park, I.B., Won, Y.Y., Jung, J.S., Jung, D.H., Sung, H.G., 2017b. An Experimental Study on Hydrodynamic Characteristics in Waves of Four Floaters in Close Proximity. Proceedings of KAOSTS 2017, 279-282.

Jung, D.W., Kim, Y.H., Jung, H.W, Park, I.B., Won, Y.Y., Jung, J.S., Jung, D.H., Cho, S.K., Sung, H.G., 2017. Assessment of Operability with Respect to the Location of Loading Arm of Floating LNG Bunkering Terminal. Proceedings of KAOSTS 2017, 69-72. 